\title{
Cashew crop propagation
}

\author{
Antonio Baldo Geraldo Martins ${ }^{1}$, Adriana de Castro Correia da Silva ${ }^{2}$, Fernando Marcelo Chiamolera ${ }^{3}$
}

\begin{abstract}
The cashew tree, a genuinely Brazilian fruit tree, is grown mainly because of its nuts and cashew nut shell liquid (CNSL), widely used in industry. Of great food importance, the cashew apple also presents economic representativeness in Brazil. With great variability, the culture has recently begun researches for improvement, with selection of new clones, more productive and with specific purpose. Usually propagated from seeds to produce new orchards, which has been replaced by vegetative propagation using the seed only for rootstocks production. Vegetative propagation by lateral grafting is the mainly technique used to multiplicated this crop, but various clonal propagation techniques, such air layering and tissue culture have been attempted. The last one, however, needs further studies because of their high costs.

Index terms: cashew nut, cashew apple, native fruit.
\end{abstract}

\section{Propagação do cajueiro}

Corresponding author: adrianacastro@uems.br

Received: March 01, 2018 Accepted: June 29, 2018

Copyright: All the contents of this journal, except where otherwise noted, is licensed under a Creative Commons Attribution License.

\begin{abstract}
Resumo - Frutífera genuinamente brasileira, o cajueiro é conhecido principalmente devido à sua castanha e ao líquido da casca da castanha (LCC), amplamente utilizada na indústria. De grande importância alimentar, o pseudofruto também apresenta representatividade econômica no Brasil, apresentando, portanto, multifinalidade de cultivo. Com grande variabilidade, a cultura teve início recente aos trabalhos de melhoramento, havendo seleção de novos clones, mais produtivos e com finalidade específica. Desta forma, a propagação seminífera, comumente utilizada para produção de novos pomares, vem sendo substituída pela propagação vegetativa, utilizando-se as sementes apenas para produção de porta-enxertos. A enxertia, por meio de garfagem lateral é a técnica mais utilizada, mas a cultura também apresenta resultados viáveis na propagação por mergulhia aérea e cultivo de tecidos. Este último, entretanto, necessita de maiores estudos devido aos seus custos, ainda elevados.
\end{abstract}

Termos para indexação: castanha de caju, pedúnculo, fruta nativa.

\section{(cc) $\mathbf{E Y}$}

${ }^{1}$ Universidade Estadual Paulista (UNESP), Faculdade de Ciências Agrárias e Veterinárias (FCAV), Departamento de Produção Vegetal. JaboticabalSP, Brasil. E-mail: abgeraldom@outlook.com (ORCID 0000-0002-4946-9104)

${ }^{2}$ Universidade Estadual do Mato Grosso do Sul (UEMS) - Unidade Universitária de Aquidauana. Aquidauana-MT, Brasil. E-mail: adrianacastro@ uems.br

${ }^{3}$ Faculdades do Centro do Paraná (UCP). Pitanga-PR, Brasil. E-mail: prof_fernandochiamolera@ucpparana.edu.br 


\section{Introduction}

The cashew tree, Anacardium occidentale, is an Anacardiaceae whose family includes trees and shrubs that develop in the tropical and subtropical regions of the Americas, Africa and Asia, although the A. occidentale species originates in Brazil, especially in the Northeast (BARROS et al., 2002). Despite being a Brazilian crop, according to FAO (2017), in 2014 Brazil was in the tenth position concerning to the world production of cashew nuts, with Nigeria, India, Côte d'Ivoire, Vietnam and Benin being the largest producers. Regarding the production of fresh fruit (cashew apple), Brazil ranks first, representing more than $90 \%$ of world production. Due to its multipurpose, the cashew tree represents a fruit of special importance for cultivation.

Paiva, Crisóstomo and Barros (2003) state that the cashew tree is a predominantly allogenic species, with a high degree of heterozygosis, so that, when variability is desired a large sample is required, which becomes very costly.

It was only in the 1950's that initiated the improvement studies, aimed at establishing productive clones and uniform orchards, and until then, the production of nut was essentially extractive. From these studies, some clones are obtained at the Pacajus Experimental Station, which became the basis for the commercial plantations, mainly CCP 76 clone. Today, more than a dozen clones are already commercially available, with selections for use as fresh fruit, nuts and multipurpose in addition to various types of environment, with and without the use of irrigation.

It is necessary to form seedlings from vegetative processes for the maintenance of the characteristics, with the obtainment of clones, changing the whole system, since until then the propagation was essentially by seed, however this type of propagation remains important both for new improvement studies as to obtain rootstocks. It is important to note that according to the specific technical standards for integrated cashew production STSICP, established by Normative Instruction / SARC 010 of August $26^{\text {th }}, 2003$, it is mandatory to use grafted seedlings or selected seeds in new orchards, for later replacement of the canopy (BRASIL, 2003).

\section{Propagation of the cashew tree}

Seed Propagation: The multiplication of the cashew tree begins with the choice of the seed for the formation of the rootstocks. The seeds (real fruits) must be collected from healthy, vigorous, productive and well-nourished mother plants, from which healthy fruits and with the characteristics of the variety are selected.
Cavalcanti Júnior, Correa and Bueno (2002) recommend to harvest the nut between 2 and 3 months after flowering, directly from the plant. Once harvested they should be separated from the cashew apple, cleaned and dried in the shade, on wire or polyethylene screens, for 5 to 10 days, to reduce the moisture content to levels close to $12.5 \%$, which will guarantee the quality and germination of the seeds. The storage, if necessary, should be done in cloth or paper bags, in ventilated, dry and covered places, for a short period of time. It is recommended to use hermetic containers and store in a cold room, at a temperature of $20^{\circ} \mathrm{C}$, for the conservation of high germinative power for periods of more than 6 months.

It is generally known that seeds with higher density result in higher germination rates and more vigorous plants because they have greater amount of reserves, however, for the cashew tree, this behavior seems to have an inverse relationship. Serrano et al. (2013), evaluating cashew clones with potential for using as rootstock, obtained negative correlations between the seed mass and the germination rate for the evaluated genotypes. Seeds of clones with smaller size and mass (CCP 06 and CCP 76) presented high germination rates, while those clones with larger size and mass had low germination rates. According to these authors, the minimum acceptable germination value for producing cashew seedlings to be economically viable is $60 \%$, and according to results obtained in this study are not indicated the use of seeds of clones BRS 274, BRS 226 and BRS 253 for ungrafted formation.

The positioning of the seed on the substrate should be with the hilum up, this is another basic sowing rule: "the seed must be sown in the same position as it is in the plant". This procedure contributes that there is no inversion of the initial development of the roots and stem, reducing the chances of plant strangulation and consequent damage to the growth. In addition, Araújo et al. (2009) recommend pretreatment of the seed, soaking it for 24 hours in water, since they observed that this treatment to be beneficial in the speed and stabilization of germination. Seedling emergence takes place 10 to 15 days after sowing. If germination does not occur in up to 12 days, new sowing should be performed (CAVALCANTI JÚNIOR, 2005). The ungrafted plants can be formed in both plastic bags and nursery tubes. Depending on the container used, we make the choice for the substrate. Preference should be given to the use of substrates without addition of soil to avoid possible contamination, but the mixture of sand, soil and organic compost is still widely used, especially in plastic bags, with positive results for the seedlings production (SUASSUNA et al., 2016).

The selection of plants should be according to vigor and erect growth, eliminating chlorotic and fragile plants, with many shoots in the neck. Thus, there will 
be greater uniformity of rootstocks, not forgetting that, because they originate from seeds, they will have variability. When the stem is about $0.5 \mathrm{~cm}$ in diameter, in the region of the graft, about $20 \mathrm{~cm}$ in height, and between 8 and 10 leaves, the seedling is able to be grafted, reaching this point between 30 and 60 days after sowing (CAVALCANTI JÚNIOR, 2005).

\section{Vegetative propagation}

Grafting: Grafting is a process of joining two or more parts of plants, which when combined will constitute a single plant with mutual benefits, for both the canopy and the root system, and the most commonly used methods are graft and budding, with their respective variations.

Graft: from the upper part (cleft graft, wedge graft, bark graft, whip graft and whip and tongue graft) and lateral (side venner graft). In this system, the graft is called fork, that consists of a branch segment approximately $6.0 \mathrm{~cm}$ long, and with more than one bud. The forks are removed from growing branches, eliminating the leaves and the apical portion, because it is very tender.

Budding: ( $\mathrm{T}$ budding, inverted $\mathrm{T}$ budding, I budding and patch budding). In this method, the graft is called budding, it consists of a small branch segment, with a single bud and about $1.5 \mathrm{~cm}$ in length.

The two processes are quite similar as to the effectiveness of the seedling production, the great difference is the availability of the grafting material due to the difference in size between them. It should be considered that, in the case of graft, despite having more tissue subject to dehydration, there is also great supply of water, nutrients and hormones, which can help in the healing, resulting in a faster bond.

It is important to note that according to the current technical standards, the origin of proof of the propagation material used is required, in this way, the seedlings must be removed from the vegetative branch in a clonal garden previously enrolled in the supervisory body (BRAZIL, 2003; CAVALCANTI JÚNIOR, 2005).

In the cashew case, Cavalcanti Júnior and Chaves (2001) advise that lateral grafting should be performed. This system is very interesting to maintain part of the leaves of the rootstock, above the grafting region, which continue to photosynthesize by providing energy for greater cell division in the bond region. Usually this system is carried out in plants with low success rate in other grafting methods.

Since the rootstock and graft reciprocal influence is known, as well as the effects of rootstocks on resistance to diseases and soil conditions, water stress, etc., several researchers have studied the combination of commercial canopies with accessible genotypes to determine the best combination.

Cavalcante (2009), studying the influence of several rootstocks on the graft, observed that clones CAC 38 and CCP 09, obtained by seeds, proved to be more adequate because they produced better quality seedlings. What had also been observed by Serrano et al. (2003) and Melo Filho et al. (2006), that using nine genetic materials, observed the influence of rootstocks on the production of cashew tree seedlings.

Cavalcanti Júnior and Corrêa (1998), studying the storage viability of propagules for grafting, for nine days, observed that conservation in vermiculite, aluminized paper and transparent plastic bag resulted in the highest percentage of grafting fixation $(90 \%)$.

Therefore, these researches show the importance of the rootstock and the evaluation of existing genotypes in the nature, even being wild, in the formation of seedlings of this species.

The time of grafting directly influences the success of the propagation, being indicated the performance in conditions of high temperatures and low relative humidity (ADEIGBE et al., 2015).

Other cashew cloning procedures, especially for tissue culture have been extensively studied; however, the results are variable, but they demonstrate the efficiency of this technique (THIMMAPPAIAH et al., 2002; MNENEY and MANTELL, 2002; ALIYU, 2005; MNENEY, 2013; MOYO and VAN STADEN, 2013). In addition, this process increases the value of the seedlings, making them not yet well accepted by producers.

Layering is a process that can also be used for cashew tree multiplication, and there is no need to use auxins for the occurrence of rooting for clone CCP 76, with rooting rates higher than $70 \%$. However, further studies are needed to evaluate the survival rate of these seedlings after transplanting (LOPES et al., 2005). The clone used also influences the success of this process, as there is variation in the rooting capacity and also in the time for it to occur (ALIYU, 2007). The use of exogenous auxins, although not increasing the percentage of the layer rooting, increases the quality of the roots formed, in quantity and size, reducing the time for rooting to occur and increasing the percentage of survival after transplant when used in concentrations of up to $3 \%$. From the exogenous auxins, IBA is the most effective (ALIYU et al., 2010).

Thus, lateral grafting is still the most efficient and accepted process for the commercial reproduction of seedlings of this species. 


\section{References}

ADEIGBE, O.O.; OLASUPO, F.O.; ADEWALE, B.D.; MUYIWA, A.A. A review on cashew research and production in Nigeria in the last four decades. Scientific Research and Essays, Nairobi, v.10, n.5, p.196-209, 2015.

ALIYU, O.M. Application of tissue culture to cashew (Anacardium occidentale L.) breeding: An appraisal. African Journal of Biotechnology, Nairobi, v.4, n.13, p.1485-1489, 2005.

ALIYU, O.M. Clonal propagation in cashew (Anacardium occidentale): effect of rooting media on the rootability and sprouting of air-layers. Tropical Science, London, v.47, n.2, p.65-72, 2007. Disponível em: $\leq \mathrm{http}: / /$ dx.doi.org/10.1002/ts.198>. Acesso em: 01 maio 2017.

ALIYU, O.M.; DADA, K.E.; HAMMED, L.A. Can auxins improve rooting of propagules and establishment of cashew clones? Fruits, Paris, v.65, p.307-314, 2010. Disponível em: $\leq$ https://doi.org/10.1051/fruits/2010026>. Acesso em: 12 ago. 2017.

ARAÚJO, J.R.G.; CERQUEIRA, M.C.M.; GUISCEM, J.M.; MARTINS, M.R.; SANTOS, F.N.; MENDONÇA, M.C.S. Embebição e posição da semente na germinação de clones de porta-enxertos de cajueiro-anão-precoce. Revista Brasileira de Fruticultura, Jaboticabal, v.31, n.2, p.552-558, 2009.

BARROS, L. M.; PAIVA, J. R.; CRISÓSTOMO, J. R.; CAVALCANTE, J. J. V. Botânica, origem e distribuição geográfica. In: BARROS, L. M. Caju: produção: aspectos técnicos. Brasília: Embrapa Informação Tecnológica, 2002. p.18-20. (Frutas do Brasil, 30).

BRASIL. Instrução normativa/SARC no 010 , de 26 de agosto de 2003. Diário Oficial da União, Poder Executivo, Brasília, DF, n.168, p.23-27, 01 set 2003. Seção 01.

CAVALCANTE, R. A. Avaliação de combinação de enxerto e porta-enxerto de cajueiro anão precoce. 2009. 52 f. Dissertação (Mestrado em Agronomia) Universidade Federal do Ceará, Fortaleza, 2009.

CAVALCANTI JÚNIOR, A.T. Mudas: padrões e exigências agronômicas. In: OLIVEIRA, V.H.; COSTA, V.S.O. (Ed.). Manual de produção integrada de caju. Fortaleza: Embrapa Agroindústria Tropical, 2005. p.111120.
CAVAlCANTI JÚNIOR, A.T.; CHAVES, J.C.M. Produção de mudas de cajueiro. Fortaleza: Embrapa Agroindústria Tropical, 2001. 43 p.

CAVALCANTI JÚNIOR, A.T.; CORREA, D.; BUENO, D. Propagação. In: BARROS, L.M. (Ed.). Caju: produção: aspectos técnicos. Brasília: Embrapa Informação Tecnológica, 2002. p.43-47. (Frutas do Brasil, 30).

CAVALCANTI JÚNIOR, A.T.; CORRÊA, M.P.F. Conservação de propágulos de cajueiro anão precoce para enxertia por borbulhia. Fortaleza: Embrapa Agroindústria Tropical, 1998. p.1-3. (Comunicado Técnico, 20).

FAO - Food and Agriculture Organization of the United Nations. Data: Production: Crops. Rome: FAOSTAT, 2017, Disponível em: <www.fao.org > Acesso em: jan. 2017.

LOPES, R. L.; CAVALCANTE, I. H. L.; OLIVEIRA, I. V. M.; MARTINS, A., B. G.; Indol-butyric acid levels on cashew cloning by air-layering process. Revista Brasileira de Fruticultura, Jaboticabal, v.27, n.3, p.517518, 2005. Disponível em: <http://dx.doi.org/10.1590/ S0100-29452005000300043>. Acesso em: 01 mai. 2017.

MELO FILHO, O.M.; COSTA, J.T.A.; CAVALCANTE JÚNIOR, A.T.; BEZERRA, M.A.; MESQUITA, R.C.M. Caracterização biométrica, crescimento de plântulas e pega de enxertia de novos porta-enxertos de cajueiro anão precoce. Revista Ciência Agronômica, Fortaleza, v.37, n.3, p.332-338, 2006.

MNENEY, E.E. Advances in tissue culture of cashew (Anacardium occidentale L.) in Tanzania. In: INTERNATIONAL CASHEW CONFERENCE, 2., 2010, Kampala. Proceedings... Wallingford: CAB International, 2013. p.45-50.

MNENEY, E.E.; MANTELL, S.H. Clonal propagation of cashew (Anacardium occidentale L.) by tissue culture. Journal of Horticultural Science and Biotechnology, Ashford, v.77, n.6, p.649-657, 2002.

MOYO, M.; VAN STADEN, J. Micropropagation of Anacardiaceae species of economic importance: advances and future prospects. In Vitro Cellular \& Developmental Biology - Plant, New York, v.49, n.2, p.85-96, 2013.

PAIVA, J. R.; CRISÓSTOMO, J. R.; BARROS, L. M. Recursos genéticos do cajueiro: coleta, conservação, caracterização e utilização. Fortaleza: Embrapa Agroindústria Tropical, 2003. 43 p. 
SERRANO, L.A.L.; MELO, D.S.; TANIGUCHI, C.A.K.; VIDAL NETO, F.C.; CAVALCANTE JÚNIOR, L.F. Porta-enxertos para a produção de mudas de cajueiro. Pesquisa Agropecuária Brasileira, Brasília, DF, v.48, n.9, p.1237-1245, 2013.

SUASSUNA, C.F.; FERREIRA, N.M.; SÁ, F.V.S.; BERTINO, A.M.P.; MESQUITA, E.F., PAIVA, E.P.; JESUS, P.L.M.; BERTINO, A.M.P. Produção de mudas de cajueiro anão precoce cultivado em diferentes substratos e ambientes. Revista Agrarian, Dourados, v.9, n.33, p.197-209, 2016.
THIMMAPPAIAH; SHIRLY, R. A.; SADHANA, P. H. In vitro propagation of cashew from Young trees. In Vitro Cellular \& Developmental Biology - Plant, New York, v.38, p.152-156, 2002. 